\title{
The Comparison of Energy Sources Used in Unmanned Air Vehicles
}

\author{
Hakan Ucgun (Corresponding author) \\ Department of Computer Engineering, Bilecik Seyh Edebali University, Bilecik, Turkey \\ E-mail: hakan.ucgun@bilecik.edu.tr \\ Ugur Yuzgec, \\ Department of Computer Engineering, Bilecik Seyh Edebali University, Bilecik, Turkey \\ Metin Kesler, \\ Department of Computer Engineering, Bilecik Seyh Edebali University, Bilecik, Turkey \\ Cagri Cicekdemir, \\ Vocational High School, Bilecik Seyh Edebali University, Bilecik, Turkey
}

\begin{abstract}
Unmanned Aerial Vehicles (UAVs) are intelligent systems that have been among the most popular technologies. UAVs have been used in many different areas, such as military, monitoring, entertainment, academic, engineering, search and rescue, border security, surveillance, cargo transportation. UAVs are the air vehicles that can be controlled by a remote control or which can move according to their abilities by means of autonomous software. Because of technological advances and facilitating the supply of used materials, the number of UAVs is increasing day by day. According to the usage area, UAVs have got many advantages and disadvantages. One of these disadvantages is undoubtedly low flight times. The low flight time of UAVs brings problems occur in accomplishing certain tasks. In order to overcome this problem, the studies are being carried out to develop energy sources. Lithium Ion (Li-ion), Lithium Ferrous Phosphate (LiFePO4), Lithium Polymer (LiPo) and Lithium Titanate batteries are used in the UAV flights. In this study, a review is presented about UAV energy sources used in past and present. In addition, the future trends in the energy sources has been examined for UAVs.
\end{abstract}

Keywords: Energy Source, Battery, LiPo, Solar Panel, PEM.

DOI: $10.7176 / \mathrm{JSTR} / 5-6-05$

\section{Introduction}

With the development of technology, many work areas have emerged and continue to emerge. In this context, Unmanned Aerial Vehicles, which are used in many different areas today, are also one of the working areas. The use of UAVs, which are used in many different areas such as military, academic, engineering, search and rescue, border security, surveillance, cargo transportation and illegal settlement, is increasing day by day thanks to technological advances and facilitation of supply of used materials. UAVs are unmanned aerial vehicle that can be autonomously controlled by means of sensors and controller card software or that can be controlled via the ground station with the help of a RC (Radio Control) supported remote control. It is frequently used in places where people cannot enter and enter where it can be dangerous for human life. In this context, UAVs can be of great importance for human life.

One of the most costly staff to train a military field is the pilot. The training of a pilot can correspond to large costs. For this reason, the fact that the unmanned aerial vehicle is lost in a problematic mission is less costly than trained personnel is lost, and it allows both material and spiritual losses to be less. This is an indication of the great importance of IDPs for human life [1]. 
Having different characteristics according to the usage purposes, the UAVs provide different advantages to the users compared to the air vehicles such as human controlled helicopter, airplane. These advantages include high maneuverability during flight, lack of commitment to limited human capabilities, autonomous flight with software support, and the ability to reach areas that are difficult to reach for people [2-3].

In addition to being such beneficial products, there are some disadvantages. One of these is the low flight duration. In addition to the hardware platform systems, the UAVs have a frame structure that hosting the controller card, sensors (gyro, acceleration, compass, pressure, gps, ultrasonic etc.), electronic speed controller, motors, propellers, camera and communication systems. They use energy sources that have different types and specifications in order to meet the power needs of the electronic components located on them.

In this study, energy source types used in the literature for unmanned aerial vehicles were researched and comparative source analyzes were presented. In the scope of the study, the unmanned aerial vehicle models in Section 2, the energy source types and technologies used in the UAVs in Section 3, the comparison results related to the study in Section 4, and conclusion and recommendations are given in Section 5.

\section{Unmanned Aerial Vehicle}

When studies on unmanned aerial vehicles were examined, it was seen that A. M. Low did the first work in 1916 [4]. In 1935, Reginald Deny developed the first UAV model with remote control. The studies carried out until 1960, along with the failure to comply with the definition of modern UAV, did not go beyond the definition of a remote control vehicle. It is based on the work of the present-day UAVs, based on years of 80's and 90's [1]. The UAVs, which have been minimized and improved these years, have been used in military areas. One of the most important reasons for this is the lack of trained military personnel and the fact that the costs of UAVs are much cheaper than in airplanes.

UAVs such as ANKA, HERON and PREDATOR [1] are used in military areas with fixed wings and are very high in cost. Due to these features, this type of aircraft is not used in other work areas. Fixed and rotary wing UAVs have been developed that can operate in many areas with low-cost to remove these troubles. UAVs are generally used different areas such as exploration, observation, supervision and hobby flights.

Depending on the design and equipment configurations, the UAVs can be divided into two groups, fixed wing and rotary wing.

\subsection{Rotary Wing $U A V$}

Rotary winged UAVs are unmanned aerial vehicles capable of stabilizing in the air by stabilizing the force generated by the different number of rotors located on them, being controllable by a remote control by the user, following the given trajectory and making vertical landing and departure.

Rotary wing UAVs are named according to their motor numbers. For example; UAV models such as TriCopter, Quad-Copter, Hexa-Copter, and Octa-Copter [5] (Figure 1.a) are frequently used in the literature. The most commonly used type is those with four rotates. In such vehicles, there are generally hardware components such as brushless DC motors, electronic speed controllers, various sensors, propellers and power system on a frame structure [6].

\subsection{Fixed Wing UAV}

Fixed-wing UAVs operate in the air with the help of a motor (internal combustion engine or electric motor), propeller and wings. The motors are used for speed reducing or increasing operations, the propellers for forward and backward operations, and the wings for orientation operations by pulling the air up and down.

The control of the fixed winged UAV is carried out through the control surfaces placed in the wing. Control surfaces include flaps, rudder and lifting systems. This system allows to the UAV freely rotate at three points that intersect at the center and are perpendicular to each other. The flaps control y-axis (Roll), the lifting control $\mathrm{x}$-axis (Pitch) and the rudder control z-axis (Yaw) [7].

Fixed wing UAVs (Figure 1.b) has a simple structure. Simple construction allows for less complex maintenance and repair operations, thus providing longer operating times at lower cost. There is no need to use large and expensive sensors in the UAV. Thanks to their natural draining ability, they can fly without power source. They allow more material to be transported with less power. 

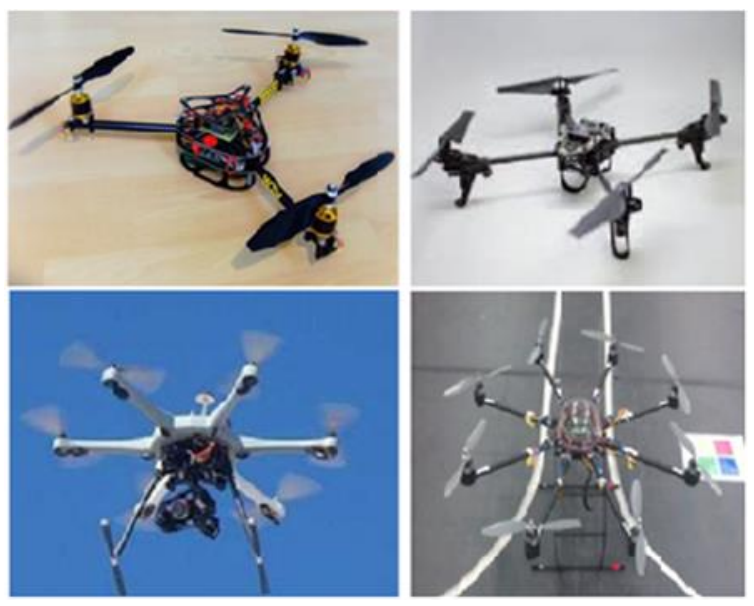

a

Figure 1. UAV Types (a. Rotary Wing UAV Types [5], b. Fixed Wing UAV Types [8, 9])

\subsection{Comparison of Rotary and Fixed Wing UAV}

There are some advantages and disadvantages between the rotary wing and fixed wing compared to each other. Some of those;

- Flight mode: Rotary wing UAVs, have advanced maneuverability, hanging, vertical landing-takeoff, turning around, turning right and left. The fixed-wing UAV performs its performance by infiltrating in the air.

- Flight Control: Rotary wing UAVs have vibration problems, extremely unstable and require advanced control algorithms to fly. The simple structuring of the fixed wing UAVs makes control easy.

- Flight Runway: Rotary wing UAVs do not require a special runway because they can do vertical landing and take-off while fixed wing UAVs need additional solutions such as special runways and catapult to make landing-take-off due to their limited maneuverability.

- Flight Time: Fixed-wing UAVs are more advantageous in terms of durability and power consumption than rotary wing UAVs.

- Flight Range: Rotary wing UAVs fly at low range and altitude while fixed wing UAVs have a high cruising speed.

- Load Capacity: Fixed wing UAVs can have more load carrying capacity than rotary wing UAVs [10].

\section{UAV Energy Sources}

Unmanned aerial vehicles, which are widely used in many areas today, use different type and specific energy source to meet the power requirements of the hardware units located on them. One of the biggest problems with these sources is flight time. The duration of the flight varies from 10 to 30 minutes with the longest flight times, depending on the characteristics of the energy sources on the UAV [11, 12].

Looking the technologies used between the UAV energy sources, it is seen that the most commonly used type of source is the batteries with lithium polymer (LiPo) characteristics. These batteries are frequently used in RC (Radio Control) model vehicles because they have the ability to refill. Looking the other sources of energy used for UAV energy sources, it is seen that renewable energy sources based solar cells [13], hydrogen-enriched proton exchange membrane (PEM) fuel cells [14], and laser technologies [15].

\subsection{LiPo Batteries and Features}

LiPo batteries are batteries that produce electrical energy by the help of chemical reactions of the lithium and polymer substances contained in them. LiPo batteries with cellular structure can be of different sizes, weights and capacities. Each cell can have a maximum 4.2V energy. LiPo batteries need to be used under control. Otherwise, safety problems such as reduced battery life, unusable cells, warming, burning can occur. So, it is worth noting that the voltage of each cell does not fall below 3.7 volts [16]. 


\section{LiPo Batteries Advantages}

One of the biggest reasons why LiPo batteries are used in $\mathrm{RC}$ vehicles is that the high current required for the vehicle can be given when needed and the battery efficiency is maintained until the end of battery life. If we look at other advantages;

- It has high energy density.

- It is lighter than other batteries.

- It can be produced in the desired shape and size.

- It has large power capacities.

- It has high discharge rates.

\section{LiPo Batteries Disadvantages}

LiPo batteries are batteries that must be taken care of during use, for a number of reasons especially safety reasons. If we look at other disadvantages;

- Requires special chargers.

- Cell loss may occur.

- It is more expensive than other batteries ( $\mathrm{NiCd}, \mathrm{NiMH}$ ).

- There may be security issues such as heating, burning, explosion, etc.

- Care must be taken to use, store and recharge.

\subsection{Solar Panels and Features}

Solar panels (Photovoltaic, PV) occurs that connecting the semiconductor solar cells inside them are connected in series or parallel. Thanks to these cells, power systems can convert the sunlight to direct current (DC) electric energy. Solar cells, which operate according to the photovoltaic principle, start to generate electrical voltage at their ends if the light touches them. The thickness of solar cells whose surfaces are generally square, rectangular or circular is usually 0.2-0.4 mm and the areas are around 100 $\mathrm{cm} 2$. In order to increase the power output, more than one solar cell is connected series or parallel and mounted on panel surface [17].

\section{Solar Panels Advantages}

- Power source is free.

- There are no harmful effects to environment.

- Maintenance costs are low.

- Simple to install with modular structure.

- It is an environmentally friendly and low cost system.

- There is an unlimited source of energy.

\section{Solar Panels Disadvantages}

- The investment cost is high.

- Large surface areas are needed.

- It may need to be stored continuously.

- The rays of the sun must come at the right angles.

- The environment of the solar panels must be clear.

- It is problematic to use in places where sunlight is low and in places.

\subsection{PEM Fuel Cells and Features}

PEM fuel cells contain two electrons, anodes and cathodes. A polymer membrane electrode separates these electrodes from each other. The fuel cell, which is thin and permeable, is powered by a polymer electrolyte in the form of a leaf. This membrane is small and light as well as working at low temperature. The fuel pump consists of three basic components, which are hardware diffusion plates, gas diffusion plates and electrolyte pairs. Individually used fuel cells have an energy production capacity of $0.6 \mathrm{~V}$. Fuel cells can be connected to each other to provide the required power capacity. Parameters that are effective in the performance of the fuel cells are considered as pressure, temperature and humidity [18].

\section{PEM Fuel Cell Advantages}

- It has high efficiency.

- There are no moving parts.

- Easy to install with silent, modular and compact design. 
- It has fast energy conversion.

\section{PEM Fuel Cell Disadvantages}

- The initial cost is high.

- Requires fuel storage for large volume or weight.

- High fuel prices may be due to the use of hydrogen.

- There is a limited life span.

\subsection{Hybrid Energy Sources}

The technologies used for energy sources can be used both individually and as a hybrid. In this context, when the studies are examined, many studies that used together solar panels, LiPo batteries and PEM fuel cells in same system can be seen [19-22]. Looking at the studies, Chen et al. [19] designed a simulated environment for solar panels and fuel cells on the UAV. In the simulation, solar panels were used as the main power source. Solar panels charge the battery and perform hydrogen electrolysis for fuel cells. Mobariz et al. [20] has performed simulations that showed the interaction between two energy sources for propulsion and load systems in system using PEM fuel cells and Li-Ion batteries.

\section{Comparison of the UAV Energy Sources}

The energy sources used in UAVs can varies in terms of features. These differences mainly consist of energy density, power density, energy costs, working life, etc. factors. In this respect, the energy characteristics (Table 1), power characteristics (Table 2), physical properties (Table 3) and operating characteristics (Table 4) of the energy sources are discussed in the comparison studies [23-25]. Graphical analysis processes were performed according to the comparison made. As a result of these analyzes, values were evaluated between 0 and 1 by normalization operations. Comparison of energy characteristics (Figure 2), power characteristics (Figure 3) and basic properties (Figure 4) are given as graphically.

Table 1. Energy Features Comparison of Energy Sources

\begin{tabular}{|c|c|c|c|}
\hline $\begin{array}{c}\text { Energy Source } \\
\text { Type }\end{array}$ & $\begin{array}{c}\text { Energy Density } \\
(\mathrm{Wh} / \mathrm{kg})\end{array}$ & $\begin{array}{c}\text { Specific Energy } \\
(\mathrm{Wh} / \mathrm{L})\end{array}$ & $\begin{array}{c}\text { Energy Cost } \\
(\$ / \mathbf{k W h})\end{array}$ \\
\hline LiPo and Li-Ion & $200-500$ & $75-200$ & $1200-4000$ \\
\hline Solar Panel & $500-10000$ & $800-100,000$ & $10,000+$ \\
\hline PEM Fuel Cell & $500-3000$ & $800-100,000$ & $10,000+$ \\
\hline
\end{tabular}

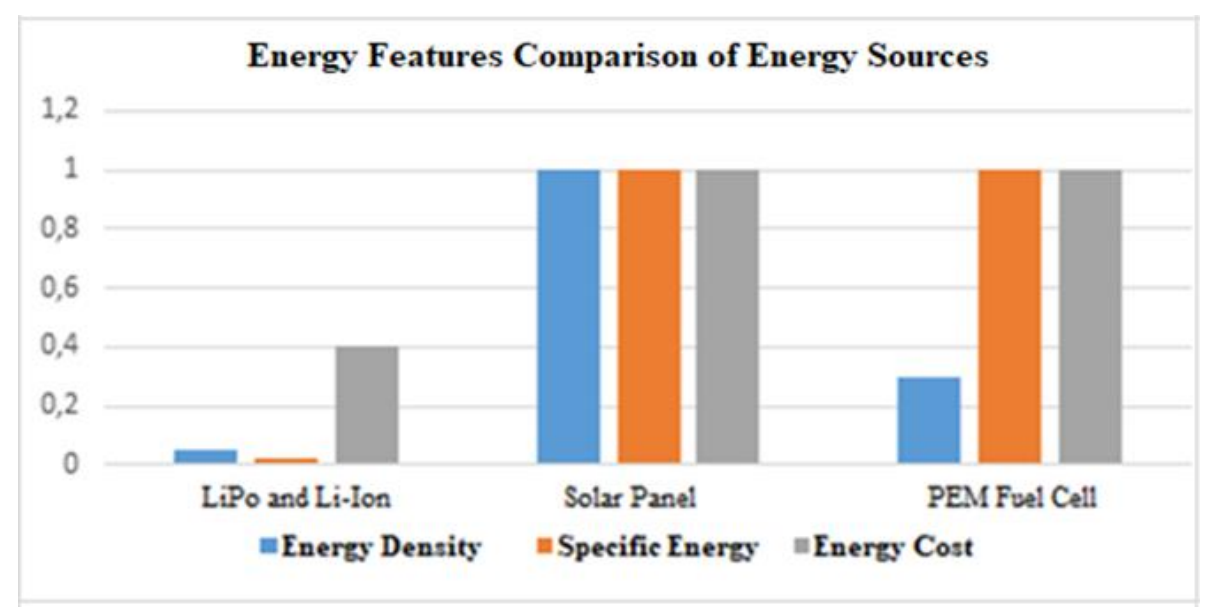

Figure 2. Graphical Representation of Energy Features Comparison 
Table 2. Power Features Comparison of Energy Sources

\begin{tabular}{|c|c|c|c|}
\hline $\begin{array}{c}\text { Energy Source } \\
\text { Type }\end{array}$ & $\begin{array}{c}\text { Power Density } \\
\text { (W/kg) }\end{array}$ & $\begin{array}{c}\text { Specific Energy } \\
(\mathbf{W} / \mathbf{L})\end{array}$ & $\begin{array}{c}\text { Energy Cost } \\
\mathbf{( \$ / k W )}\end{array}$ \\
\hline LiPo and Li-Ion & $1500-10,000$ & $150-315$ & $1200-4000$ \\
\hline Solar Panel & - & - & - \\
\hline PEM Fuel Cell & $500+$ & $500+$ & 500 \\
\hline
\end{tabular}

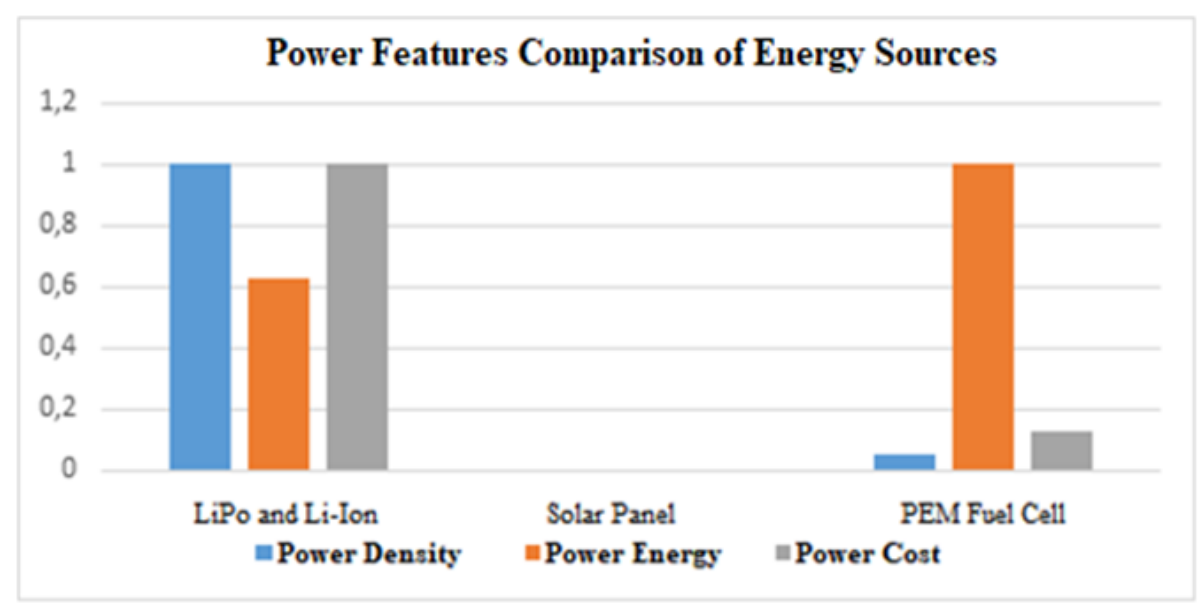

Figure 3. Graphical Representation of Power Features Comparison

Table 3. Power Features Comparison of Energy Sources

\begin{tabular}{|c|c|c|c|}
\hline $\begin{array}{c}\text { Energy Source } \\
\text { Type }\end{array}$ & Power Rate & Discharging Time & Environment Effect \\
\hline LiPo and Li-Ion & $0-100 \mathrm{~kW}$ & Minute - Hours & Ineffective \\
\hline Solar Panel & $0-10 \mathrm{MW}$ & Second $-24+$ Hours & Ineffective \\
\hline PEM Fuel Cell & $0-50 \mathrm{MW}$ & $1-24+$ Hours & Negative \\
\hline
\end{tabular}

Table 4. Working Conditions Comparisons of Energy Sources

\begin{tabular}{|c|c|c|c|}
\hline $\begin{array}{c}\text { Energy Source } \\
\text { Type }\end{array}$ & $\begin{array}{c}\text { Lifespan } \\
\text { (Year) }\end{array}$ & $\begin{array}{c}\text { Cycle Time } \\
\text { (Cycle) }\end{array}$ & Temperature \\
\hline LiPo and Li-Ion & $+/-10$ & $1000-10000+$ & $0{ }^{\circ} \mathrm{C}-45^{\circ} \mathrm{C}$ \\
\hline Solar Panel & $+/-20$ & - & $-40^{\circ} \mathrm{C}-85^{\circ} \mathrm{C}$ \\
\hline PEM Fuel Cell & $+/-1$ & $1000+$ & $+25^{\circ} \mathrm{C}-80^{\circ} \mathrm{C}$ \\
\hline
\end{tabular}

Table 5. Basic Features Comparison of Energy Sources [26]

\begin{tabular}{|c|c|c|c|}
\hline $\begin{array}{c}\text { Energy Source } \\
\text { Type }\end{array}$ & $\begin{array}{c}\text { Energy Density } \\
(\mathbf{W h} / \mathbf{k g})\end{array}$ & $\begin{array}{c}\text { Energy Cost } \\
\mathbf{( \$ / W h )}\end{array}$ & $\begin{array}{c}\text { Lifespan } \\
\text { (Year) }\end{array}$ \\
\hline LiPo and Li-Ion & 5 & 0.82 & $+/-10$ \\
\hline Solar Panel & 533 & 0.17 & $+/-20$ \\
\hline PEM Fuel Cell & 200 & 0.46 & $+/-1$ \\
\hline
\end{tabular}




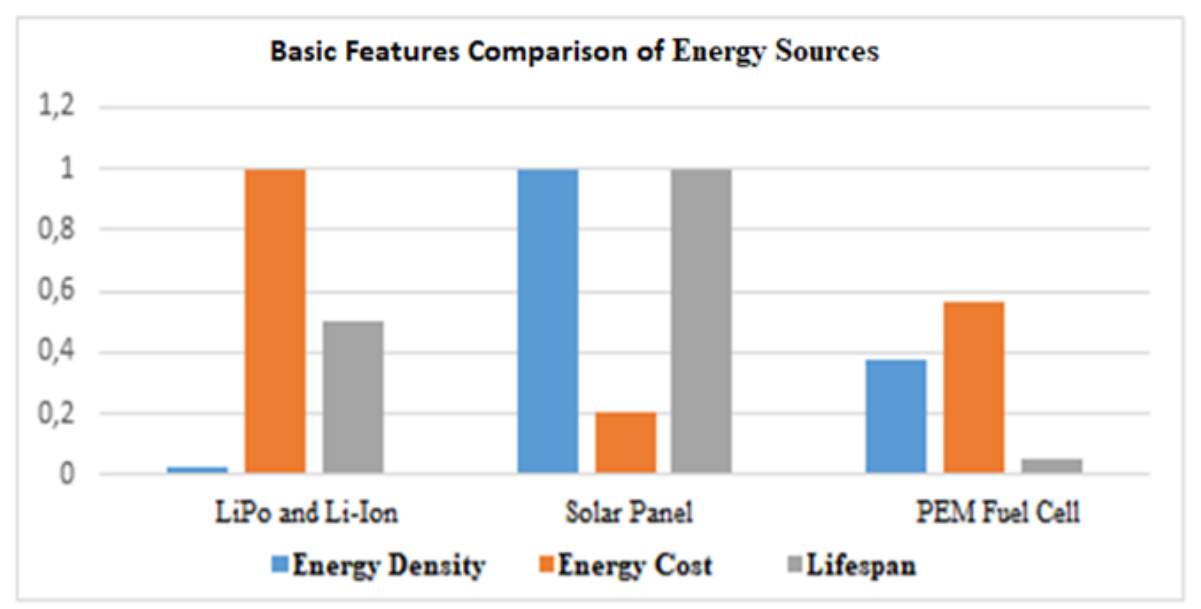

Figure 4. Graphical Representation of Basic Features Comparison

\section{Conclusion}

The energy problem has always caused problems for mankind. Despite some solutions to the energy problem with the progress of the technology, the search for new energy sources is still ongoing. Many emerging technological products are used for the benefit of human beings and provide some facilities. The energy requirement of such products is undeniable for users. One of these products is the unmanned aerial vehicles. The UAVs, which have begun to be used primarily in the military field are then that have been included in the literature in parallel with the progress of the technology and have begun to be used in different fields are unmanned vehicles.

UAVs are increasing their popularity day by day and continues use in many areas. As with every electronic device, the energy problem in the UAVs also causes some problems for its users. The low flight times are one of the biggest problems for UAVs. To solve this problem, new energy sources are being investigated. Research on different energy sources is still ongoing. In this context, it is possible to encounter UAV studies using various energy sources. In the study, solar panels, LiPo batteries and PEM cells were investigated from sources used for UAVs.

Within the scope of the study, various energy sources used in hardware and simulation applications for UAV were researched and comparative analyzes were made. In this study, research related with LiPo batteries, solar panels and PEM fuel cells has been conducted. The energy sources used in the study are compared in terms of their characteristics such as energy density, power density, cost, lifespan and discharge time. The results obtained from the comparisons were analyzed graphically.

In today's technology, theoretical and practical studies for renewable energy-driven UAVs have increased considerably. Altough, it can be seen that the yields of rotary winged UAVs are not enough. When looking at fixed-wing studies, it is seen that applications that are more efficient are made in terms of power supply due to the wide and long frame structure [27]. The main reason for this difference is that the power obtained from the solar panels is low. Since the fixed wing UAVs have long wing openings, solar panels are installed as desired. The use of solar panels in fixed-wing UAVs is more suitable than rotary-wing UAVs.

LiPo batteries, one of the most frequently used power supplies in UAVs, have more power than solar panels and fuel cells. However, the amount of weight in these sources and the low level of the occupancy rate is a big disadvantage for the users. The batteries need to be replaced in about 10-15 minutes. However, they are now widely used in UAVs and RC vehicles. With the advancement of technology, it is foreseen that batteries with different chemical properties [28, 29] will replace these batteries.

\section{References}

1. Vikipedi, İnsansız Hava Arac1. (2019), [Online] Available: https://tr.wikipedia.org/wiki/İnsansız hava_arac1 (May 31, 2019 ) 
2. Ertin, O.B. 2013. Sabit Kanatı Bir İnsansız Hava Aracı İçin Otopilot Sistemi Geliştirmede Döngüde Donanım Tabanlı Yaklaşım. TOBB Ekonomi Ve Teknoloji Üniversitesi, Fen Bilimleri Enstitüsü, Yüksek Lisans Tezi, 88s, Ankara

3. Dikmen, İ.C. et al. (2010). Dikey İniş-Kalkış Yapabilen Dört Rotorlu Hava Aracının(Quadrotor) Uçuş Kontrolü, Havacılık Ve Uzay Teknolojileri Dergisi, 4:33-40.

4. Taylor, J.W.R., Jane's pocket book of remotely piloted vehicles, Collier Books, London, 1977

5. Agrawal, K. et al. (2015). Multi-rotors: A Revolution In Unmanned Aerial Vehicle, International Journal of Science and Research (IJSR), 4:1800-1804.

6. Üçgün, H. et al. (2016). Dört Rotorlu Döner Kanat İnsansız Hava Aracı Test Düzeneği Geliştirilmesi, EEB 2016 Elektrik-Elektronik ve Bilgisayar Sempozyumu, Tokat, Türkiye

7. Fixed Wing Versus Rotary Wing For UAV Mapping Applications. (2019), [Online] Available: https://www.questuav.com/media/case-study/fixed-wing-versus-rotary-wing-for-uav-mappingapplications/ (May 31, 2018)

8. Chao, H. et al. (2007). Autopilots for Small Fixed-Wing Unmanned Air Vehicles: A Survey, IEEE International Conference on Mechatronics and Automation, Harbin.

9. Colomina, I. et al. (2014). Unmanned aerial systems for photogrammetry and remote sensing: A review. ISPRS Journal of Photogrammetry and Remote Sensing, 92:79-97.

10. Şengül, B., Döner Kanatlı İHA'lar ile Sabit Kanatlı İHA'ların Karşılaştırılması. (2019), [Online] Available: $\quad$ https://prezi.com/y 6abbpq2r-w/doner-kanatl-ihalar-ile-sabit-kanatl-iha039larnkarslast/ (May 31, 2019)

11. Chang, K. et al. (2016). Lipo battery energy studies for improved flight performance of unmanned aerial systems. International Society for Optics and Photonics SPIE Defense+ Security, 98370W98370W.

12. Morbidi, F. et al. (2016). Minimum-Energy Path Generation for a Quadrotor UAV, IEEE International Conference on Robotics and Automation, Stockholm, Sweden

13.Zafar, S. et al. (2015). Energy Harvesting using Small Renewable Energy Sources: UAV Application, ASME 2015 International Mechanical Engineering Congress and Exposition IMECE2015, Houston, Texas.

14. Kim, T., (2014). NaBH4 (sodium borohydride) hydrogen generator with a volume-exchange fuel tank for small unmanned aerial vehicles powered by a PEM (proton exchange membrane) fuel cell, Energy, 69: 721-727

15. Nugent, T,J,Jr. et al. (2011). Laser power beaming for defense and security applications, SPIE Defense+ Security, pp. 804514-804514-8, https://doi.org/10.1117/12.886169.

16. Batteries for UAV. (2019), [Online] Available: http://dronesarefun.com/BatteriesForUAV.html (May31, 2019)

17. Solar Academy, Güneş Enerjisi, Güneş Panelleri, PV-PhotoVoltaic nedir?. (2019), [Online] Available: http://www.solar-academy.com/menu_detay.asp?id=2986, (May 31, 2019)

18. İçingür, Y. et al. (2011). Bir Polimer Elektrolit Membran Yakıt Pilinde Kullanılmak Üzere Gaz Akış Plakaları Tasarımı ve Denenmesi, Politeknik Dergisi, 14:31-37. 
19. Chen, H. et al. (2010). Hybrid Energy Storage System for Unmanned Aerial Vehicle (UAV), IECON 2010 - 36th Annual Conference of IEEE Industrial Electronics, Glendale, AZ, USA.

20. Mobariz, K.N. et al. (2015). Long endurance hybrid fuel cell-battery powered UAV, World Journal of Modelling and Simulation, 11:69-80.

21. Bongermino, E. et al. (2017). Model and Energy Management System for a Parallel Hybrid Electric Unmanned Aerial Vehicle, IEEE 26th International Symposium on Industrial Electronics (ISIE), Edinburgh, UK.

22. Dudek, M. et al. (2013). Hybrid Fuel Cell - Battery System as a Main Power Unit for Small Unmanned Aerial Vehicles (UAV), Int. J. Electrochem. Sci., 8:8442-8463.

23. Chen, H. et al. (2009). Progress in electrical energy storage system A critical review, Progress in Natural Science, 19:291-312.

24. Krawczyk J.N. et al. (2014). Fuel Cells as Alternative Power for Unmanned Aircraft SystemsCurrent Situation and Development Trends, Transactions of the Institute of Aviation, 4:49-62.

25. Akinyele, D.O. et al. (2014). Review of energy storage technologies for sustainable power networks, Sustainable Energy Technologies and Assessments, 8:74-91.

26. Botha, C.M., et al. (2008). Considerations for Optimal Renewable Energy Power Sources in Unmanned Aerial Vehicle Applications.

27.Top 8 Solar Powered Drone (UAV) Developing Companies, (2019), [Online] Available: https:// sinovoltaics.com/technology/top8-leading-companies-developing-solar-powered-drone-uavtechnology/ (May 31, 2019)

28.Baes, K., et al. (2018), Future of batteries, Winner takes all? (2019), [Online] Available; https://www.adlittle.com/sites/default/files/viewpoints/adl_future_of_batteries-min.pdf (May 31, 2019)

29. Science for Environment Policy Towards the battery of the future. Future Brief 20. Brief produced for the European Commission DG Environment by the Science Communication Unit, UWE, Bristol, (2019), [Online] Available; http://ec.europa.eu/science-environment-policy, (May 31, 2019) 